\title{
Relationship Between SMEs Sources of Funds and Investment Evaluation Techniques
}

\author{
Rose Jestina Katabi ${ }^{1}$, Romanus Dimoso ${ }^{2}$ \\ ${ }^{1}$ School of Business, Mzumbe University, Morogoro, Tanzania \\ ${ }^{2}$ Faculty of Social Sciences, Mzumbe University, Morogoro, Tanzania \\ Correspondence: Rose Jestina Katabi, School of Business, Mzumbe University, Morogoro, Tanzania.
}

Received: November 21, 2018

Accepted: December 29, 2018

Online Published: December 29, 2018

doi:10.11114/bms.v4i4.3780

URL: https://doi.org/10.11114/bms.v4i4.3780

\begin{abstract}
This paper analysed the sources of funds that influence the selection of investment evaluation techniques of SMEs in Tanzanian. Cross-sectional survey design was used to explain the sources of funds influencing the selection of investment evaluation techniques among Tanzanian SMEs. Purposive sampling technique was used to collect data to a sample of 301 SMEs drawn from SIDO in Dar es Salaam and Dodoma regions. Data were collected though questionnaires and transformed into suitable format for analysis using statistical packages for the survey, while for the case study interviews were used. Statistical techniques used in this study were descriptive (frequency distributions, tabulation, and cross-tabulation) and inferential statistics (bivariate analysis, and multivariate analysis) which were used to determine whether or not there is a relationship between sources of funds of SMEs, and investment evaluation techniques. The findings of the study revealed that personal saving and commercial banks were found to be factors influencing the selection of investment evaluation techniques.
\end{abstract}

Keywords: relationship, sources of funds, SMEs, investment evaluation techniques

\section{Introduction}

It is now increasingly recognized that the small business plays an important role in income generation as well as employment generation around the world (Omar, 2008; Abanis et al 2013; Karadag, 2015).In Tanzania, the Small and Medium Enterprises Development Policy states that, the small and medium enterprises cover non-farm economic activities mainly manufacturing, mining, commerce, and services (URT, 2003). The common yardsticks are total number of employees, total investments and sales turnover. The Small and Medium Enterprises further elaborates that, micro enterprises are those engaging up to 4 people, in most cases family members or employing capital amounting up to Tshs.5.0 million (URT, 2003). The majority of micro enterprises fall under the informal sector. Small enterprises are mostly formalised undertakings engaging between 5 and 49 employees or with capital investment from Tshs. 5 million to Tshs. 200 million. Medium enterprises employ between 50 and 99 people or use capital investment from Tshs.200 million to Tshs. 800 million. Studies indicate that formal SMEs contribute up to $45 \%$ of employment and up to $33 \%$ of GDP in developing countries (IFC, 2010). SMEs are estimated to contribute 30-35\% of the gross domestic product. Uddin and Chowdhury (2009) pointed out that, although small businesses seem "small" collectively it is huge and significant for an economy. Many countries are becoming much more serious about developing small business sector. Therefore understanding the pattern of their investment decisions is important (Uddin and Chowdhury, 2009).

Investment decision or capital budgeting decision may be defined as the firm's decision to invest its current funds most efficiently in the long-term assets in the anticipation of an expected flow of benefits over a series of years (Pandey, 1976; Weston and Brigham, 1981). When a business makes a capital investment, it incurs a current cash outlay in the expectation of future benefits. Usually, these benefits extend beyond one year in the future (Van Horne \& John Wachowiz, 1995). In short, the investment decisions deals with the question of what assets should a business acquire (Srivastava \& Misra, 2008). The investing decision or capital budgeting decisions are very important to the firm, since they tend to determine its value by influencing its growth, profitability, and risk (Pandey, 1976). Hence, businesses need to make sure that they are making the right decision on deciding about what investments to undertake. One of the tools which can assist owners or decision makers of Small and Medium Enterprises (SMEs) to evaluate and select investment projects is the investment evaluation techniques. These techniques are grouped into two; discounted cash flow methods 
and non- discounted cash flow methods (Pandey, 1976).

Several studies have been conducted on investment decision practices, and on the use of investment evaluation techniques in different countries. These studies are : Danielson and Scott, (2006) in USA; Vos and Vos(2000) in New Zealand; Graham and Harvey (2001) in Canada; Brijlal and Quesada (2009) in South Africa; Olawale et al (2010) in South Africa; Mukherjee and Henderson (1987) in UK; Awomewe and Ogundele (2008) in European, American, and African companies; John (2007) in Tanzania; Kipesha (2009) in Tanzania. These studies in most cases indicated the most widely used investment technique. However, it is most important to know beyond the reasons given for the use of an investment evaluation technique by understanding the influence on the selection and adoption of a certain investment evaluation technique. Knowing these factors may assist SMEs in making better investment decisions on selecting the right investment evaluation techniques. Sources of funds can be one of the factors that can influence how SMEs select investment evaluation techniques as highlighted in the two theories of investments: first, the theory of investment decisions which assumes that a firm has access to perfect financial markets allowing it to finance all value enhancing projects (Danielson and Scott, 2006). Second, the cash flow theory of investment which argues that what matters for investment is the availability, and that investment is positively related to internal finance (Samuel, 1996). This study therefore, aimed to investigate the sources of funds which influence the selection of investment evaluation techniques of SMEs in Tanzania.

This paper is organized into six sections. The first section covers the introduction of the paper whereby the background of the problem is discussed. Section two is on the literature review; this is followed by section three which presents the methodology of the study. Section four presents the findings of the study. Section five and six are on the discussion of the findings and conclusions respectively. Lastly are the references.

\subsection{Literature Review}

\subsubsection{Sources of Funds}

Investments need to be financed from various sources which can include equity finance, debt finance, and government assistance. Under the equity finance the majority of SMEs in developing countries meet their financing need through internal sources and bank loans (Al-kharus 2003; Makoni, 2014). Owners' personal savings have been shown in most researches to be the most important source of equity finance for new SMEs (Bates and Hally, 1989; Van Auken and Carter, 1993; Levy 1993, Liaw, 1999). Small businesses rely primarily on personal savings for start-up (He \& Baker, 2007). However, most of them still need access to outside finance in order to survive or grow (Mason et al., 1998). On the other hand, under debt finance many SMEs which require external finance prefer to use debt as a source of finance and other lending institutions, particularly banks are the most usual source of this kind of finance (Keasey and Watson, 1993; He and Baker, 2007; Makoni, 2014). The other type of finance is government assistance. One of the important sources of external finance for small businesses is through government assistance; such incentives can boost the overall resources of a business, particularly in the form of grants or low-interest loans (Oakey, 1984).

Ahmed (2013) observed a positive relationship between the availability of cash and the technique used for investment decision. It is argued that businesses with large cash balance which are classified as liquid companies have an opportunity to make new investments (ibid). Hence, the findings indicate that businesses with more cash balances tend to use more excessively NPV and APV, but they are negatively correlated with payback period, SA, ARR, and IRR. On the other hand, Danielson and Scott (2006) argued that wait for cash is significantly positive for payback period and DCF analysis. This means that because of financial constraints to fund all valuable investments, the business will evaluate projects using payback period to help it allocate funds over a multiyear horizon; or discounted cash flow analysis to help identify the best investments.

Carrascal and Ferrando (2008) argue that financial position of the firm is important to explain capital expenditures. The financial position of the business is explained by the source of funds available to the business. Capital expenditures can be analysed using different types of investment evaluation techniques. Therefore, the above argument could mean that the source of fund could influence the selection of investment evaluation technique used by small businesses.

\subsubsection{Investment Evaluation Techniques}

There are a number of investment evaluation techniques which are in use. These may be grouped into two; Discounted cash flow techniques and Non- discounted cash flow techniques (Pandey, 1976). In the first group there are three methods: Net Present Value (NPV), Internal Rate of Return (IRR), Modified Internal Rate of Return (MIRR), and Profitability Index. While in the second group there are three methods as follows; Pay Back (PB), Discounted Payback, and Accounting Rate of Return (ARR).

\subsubsection{Conceptual Framework}

The main question addressed in this study is, "what is the influence of sources of funds on the selection of investment 
evaluation techniques used by SMEs'? The literature review has revealed the importance of investment decisions, and that investments are to be evaluated using laid down criteria. However, the selection of investment evaluation techniques can be influenced by the sources of funds such as personal savings, commercial banks, family and friends, government assistance programmes, and other sources. Hence the general study relationship among study concepts can be suggested from the literature review: sources of funds on one hand and investment evaluation techniques on the other. The conceptual framework developed for this study is shown in Figure 1.

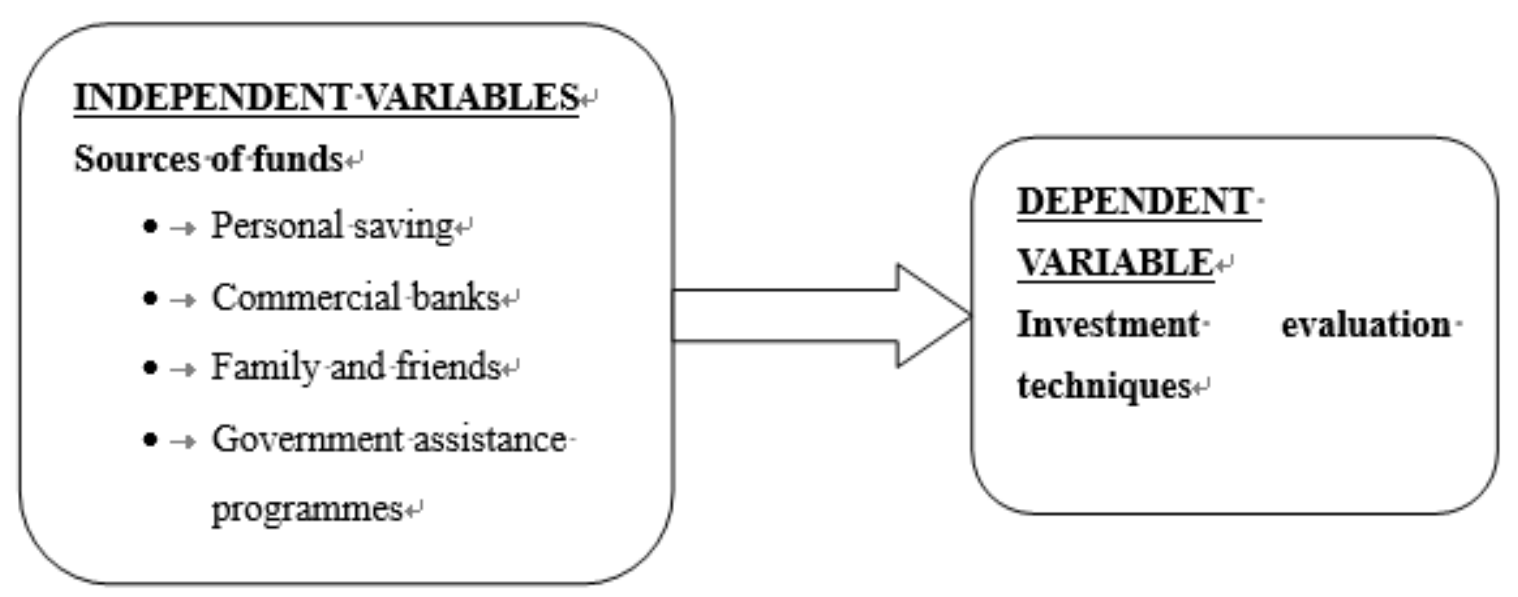

Figure 1. Conceptual framework

\section{Source: Own construction derived from literature review}

\subsubsection{Hypothesis for the Study}

From the literature review, there are various sources of funds for small businesses. These sources of funds could be personal savings, commercial banks, family and friends, government assistance programmes, and other sources. Studies conducted by Danielson and Scott (2006), and Ahmed (2013) observed a positive relationship between availability of cash and technique used for investment decision. The hypothesis to test the relationship between sources of funds and investment evaluation technique can be stated as follows:

\section{$\mathrm{H}_{1}$ : sources of funds positively influence the selection of investment evaluation techniques used by SMEs.}

\section{Method}

This study was conducted in Tanzania specifically in Dar es Salaam and Dodoma regions to analyse the sources of funds which influence the selection of investment evaluation techniques among Tanzanian SMEs. The study was conducted in two stages; firstly, a written survey was carried out and secondly, as a case study.

\subsection{Sampling Technique and Data Collection}

This study was conducted in Tanzania, and two regions namely; Dar es Salaam and Dodoma, were chosen having high population of SMEs as indicated from SIDO Directory. A non- probability sampling method known as purposive sampling was used to get a sample of 301 respondents which met the following criteria: the SMEs employing from 5 up to 99 people or capital investment of from 5 up to 800 million shillings, the SMEs which is in the manufacturing, service and distribution sectors of business, and involved in local business, the contact respondent was limited to the owner, the manager, or the finance manager. In this study, the term SMEs is used interchangeably with small business to describe small and medium-sized enterprises. In Tanzania, a micro enterprise is defined as a firm with fewer than five employees, whereas a small firm is a firm with 5 to 49 employees and a medium-sized enterprise is a firm with 50 to 99 employees. Data were collected using the questionnaire and personal interviews.

Respondents were supplied with written questionnaire to fill in data and necessary information regarding the study. The personal interview method was appropriate for collecting data from SMEs owners. This method was useful for questions that required probing to obtain adequate information (Walliman, 2011).

\subsection{Data Analysis}

Data analysis involved two phases namely; descriptive analysis and inferential analysis. Descriptive analysis involved construction of statistical distribution and calculation of simple measures like averages and percentages for describing 
the features of the research aggregate. In order to measure the association between investment decision criteria and sources of funds of the SMEs, the multiple regression model was used to analyse the sources of funds influencing the selection of an investment evaluation methods made by SMEs. The model is as shown below:-

$$
D V=\alpha+\beta_{1} \chi_{1}+\beta_{2} \chi_{2}+\beta_{3} \chi_{3} \ldots \ldots \ldots+\beta_{n} \chi_{n}+\varepsilon
$$

Where,

$D V=$ the frequency of using investment evaluation technique.

$\chi_{1} \ldots \ldots \chi_{\mathrm{n}}=$ sources of funds i.e. personal savings, family and friends, commercial banks, government

assistance programmes, etc.

$\alpha, \beta_{1} \ldots \ldots . \beta_{n}=$ Regression Coefficients

$\varepsilon=$ Error variable

Inferential analysis on the other hand was concerned with drawing inferences and conclusions from the findings of the study. Data was first analysed through descriptive statistics and regression analysis and thereafter interpretation was done.

\subsection{Study Variables}

This study analysed the sources of funds influencing the selection of investment evaluation techniques of SMEs in Tanzania. The investment evaluation techniques included; discounted cash flow methods (NPV, IRR, PI, and MIRR), Non- discounted cash flow methods (payback period, and accounting rate of return), and gut feel/ intuition. Table 1 shows how investment evaluation techniques were measured.

Table 1. Measurement of investment evaluation techniques

\begin{tabular}{lllrrr}
\hline Variable & Dimension & Indicators/Measurement & Variable type \\
\hline Investment & DCF techniques(NPV, IRR, PI, & Likert scale (Hartwig and & Ratio \\
evaluation & MIRR) & Daunfeldt, 2012; Vos eand & \\
technique. & $\begin{array}{l}\text { Non- DCF techniques(payback } \\
\text { period, ARR) and gut 2000; Graham and }\end{array}$ & \\
& $\begin{array}{l}\text { feel/intuition } \\
\text { farvey, 2001). }\end{array}$ & & \\
& & & & & \\
\end{tabular}

\section{Source: Literature Review}

Similarly the literature review has shown that the source of funds influence the selection of investment evaluation technique. To capture sources of funds in this study, categories of sources of funds were presented in Table 2 as follows; personal savings, family and friends, commercial banks, government assistance programmes, and any other source.

Table 2. Measurement of sources of Funds

\begin{tabular}{llll}
\hline Variable & Dimensions & Indicators/ measurement & Variable type \\
\hline Sources of funds & Sources of funds & Sources of funds for a business & Nominal \\
& & in categories: personal savings, \\
& family and friends, commercial \\
& banks, government assistance, \\
& any other source (He and \\
& Baker, 2007).
\end{tabular}

\section{Source: Literature Review}

\subsection{Case Study}

In order to understand more on the sources of funds influencing the selection of investment evaluation techniques, case study strategy was used apart from the survey strategy. According to Yin (2003), the case study research can be exploratory, descriptive, or explanatory. This study adopted explanatory case study because it intended to examine closely in order to explain the sources of funds influencing the selection of investment evaluation techniques in the SMEs of Tanzania. The study was conducted in Dar es Salaam involving five purposively selects SMEs.

\section{Results}

\subsection{Sample Description}


This study used purposive sampling technique to select a sample of SMEs from SIDO in DSM and Dodoma regions. A sample of 301 SMEs was used for the survey and 5 SMEs for case study. In this study in terms of SMEs characteristics, it is indicated that most small businesses are in manufacturing activities (44.5\%), and are sole proprietors $(60.5 \%)$, and reports a higher sales growth $(48.2 \%)$ in the past two years. However, these SMEs are young in terms of age, from one to five years $(45.8 \%)$, and number of employees from one to five employees $(64.5 \%)$. At the same time, in terms of characteristics of owners, it is indicated that most SMEs are dominated by female (51.8\%), and most respondents are owners of the business (75.1\%). As far as formal and finance education is concerned, most SMEs owners do not have degrees (39.9\%). These SMEs most of them are run by owners who are less than 54 years of age (84.6\%).

\subsection{Descriptive Statistics for Investment Decision Criteria}

The investment evaluation methods used to assess the financial viability of a major investment in the business for the purpose of this study are presented in Table 3. Results indicate that the first used method is gut feel $96(31.8 \%)$, and second used method is the payback period $86(28.6 \%)$. this is followed by Accounting Rate of Return 83(27.6\%), and 2 $(0.7 \%)$ used combined methods. $34(11.3 \%)$ did not indicate the methods used to evaluate investments.

Table 3. Investment evaluation techniques

\begin{tabular}{lll}
\hline Investment evaluation technique & Number of observations & percent \\
\hline Payback period & 86 & 28.6 \\
Accounting rate of return & 83 & 27.6 \\
Gut feel or intuition & 96 & 31.8 \\
Combination & 2 & 0.7 \\
No method & 34 & 11.3 \\
Total & $\mathbf{3 0 1}$ & $\mathbf{1 0 0 . 0}$ \\
\hline
\end{tabular}

Source: Field data with own computation

\subsection{Descriptive Statistics of Sources of Funds}

Table 4. below presents the sample distribution of sources of funds in the past. It is indicated that on starting the business, 219(72.8\%) of SMEs were financed from personal savings, 36(12\%) from commercial banks, $27(9 \%)$ from family and friends, $14(4.7 \%)$ from government assistance programmes.

Table 4. Source of funds in the past

\begin{tabular}{lll}
\hline Source of funds in the past & Observations & Percent \\
\hline Personal savings & 219 & 72.8 \\
Family and friends & 27 & 9.0 \\
Commercial banks & 36 & 12.0 \\
Government assistance programmes & 14 & 4.7 \\
Other & 4 & 1.3 \\
No answer & 1 & 0.3 \\
Total & $\mathbf{3 0 1}$ & $\mathbf{1 0 0}$ \\
\hline
\end{tabular}

Source: Field data with own computation

Regarding the level of importance of financial services as presented in Table 5, 190(63.1\%) considered personal savings to be very important, 54(17.9\%) considered assistance from family and friends to be very important, 38(12.6\%) of SMEs considered that government assistance programmes are very important to them, and 47(18.9\%) considered bank services to be very important source of funds.

Table 5. Level of importance of financial services

\begin{tabular}{|c|c|c|c|c|c|c|}
\hline \multirow[t]{2}{*}{ Type of service } & \multicolumn{6}{|c|}{ Level of importance of financial services } \\
\hline & Not at all & Slightly & Moderately & Important & Very important & No answer \\
\hline Personal savings & $36(12 \%)$ & $16(5.3 \%)$ & $14(4.7 \%)$ & $23(7.6 \%)$ & $190(63.1 \%)$ & $22(7.3 \%)$ \\
\hline Friends and family & $31(10.3 \%)$ & $33(11 \%)$ & $57(18.9 \%)$ & $77(25.6 \%)$ & $54(17.9 \%)$ & $49(16.3 \%)$ \\
\hline Government assistance programmes & $81(26.9 \%)$ & $42(14 \%)$ & $65(21.6 \%)$ & $37(12.4 \%)$ & $38(12.6 \%)$ & $38(12.6 \%)$ \\
\hline Bank services & $104(34.6 \%)$ & $35(11.6 \%)$ & $26(8.6 \%)$ & $32(10.6 \%)$ & $57(18.9 \%)$ & $47(15.6 \%)$ \\
\hline
\end{tabular}

Source: Field data with own computation 
This study was interested to know which financial service was more important to SMEs. Table 6 below shows the mean values and standard deviation of the financial services of SMEs. Higher mean values indicate the most important financial service, in this case personal savings. For that matter, personal savings is the most important financial service for SMEs.

Table 6. Average importance of financial services

\begin{tabular}{lll}
\hline Variable & Mean & Standard deviation \\
\hline Personal savings & 4.129032 & 1.453543 \\
Friends and family & 3.396825 & 1.368859 \\
Government assistance programmes & 2.653992 & 1.413557 \\
Bank services & 2.61811 & 1.632134 \\
\hline
\end{tabular}

Source: Field data with own computation

There are situations whereby there is an investment opportunity but the business lack cash. So, in case of lack of cash as shown in Table 7, 160(53.2\%) of SMEs will borrow money and make investments, $79(26.2 \%)$ will seek for outside investor, while 55(18.3\%) will wait until they accumulate enough cash.

Table 7. What the business will do in case of lack of cash

\begin{tabular}{lll}
\hline In case of lack of cash & Observation & Percent \\
\hline Wait until you accumulate enough cash & 55 & 18.3 \\
Borrow money and make investment & 160 & 53.2 \\
Seek outside investor & 79 & 26.2 \\
Other & 4 & 1.3 \\
No answer & 3 & 1.0 \\
Total & $\mathbf{3 0 1}$ & $\mathbf{1 0 0}$ \\
\hline
\end{tabular}

\section{Source: Field data}

\subsection{Correlation Analysis}

Before performing multiple regression analysis, the relationship between variables is investigated through correlation analysis. If variables are highly correlated it indicates that there is a possibility of multicollinearity between variables. Hence, the correlation coefficient should be less than 0.7 to show that there is no possibility of multicolinearity. The correlation matrix for the association is presented in the following sections.

The correlation between frequency of using investment evaluation techniques and sources of funds is depicted in Table 8 below. The table shows a summary of correlation coefficients measuring association between the frequency of using investment evaluation techniques and sources of funds. The correlation coefficients of a two-tailed relationship were tested using a t-test at the levels of $5 \%$ and $1 \%$. It is indicated that there are five variables which are statistically correlated. The frequency of using ARR is positively correlated with the frequency of using payback period at $1 \%(\mathrm{r}=$ 0.595). Frequency of using payback period is negatively correlated with commercial banks at $1 \%(\mathrm{r}=-0.170)$. Gut feel was negatively correlated with commercial banks at $5 \%(\mathrm{r}=-0.147)$. Family and friends is negatively correlated with commercial banks at 5\% $(\mathrm{r}=-0.116)$.

Table 8. Correlation analysis between investment evaluation techniques and sources of funds

\begin{tabular}{llllllll}
\hline & 1 & 2 & 3 & 4 & 5 & 6 & 7 \\
\hline Frequency of utilizing payback period 1 & &. & & & \\
Frequency of utilizing ARR & $.595^{* *}$ & 1 & & & & \\
Frequency of utilizing gut feel & .022 & .059 & 1 & & & \\
Family and friends & -.024 & .072 & -.065 & 1 & & \\
Commercial banks & $-.170^{* *}$ & $-.371^{* *}$ & $-.147^{*}$ & $-.116^{*} 1$ & \\
Government assistance programmes & .115 & .082 & .066 & -.069 & -.081 & 1
\end{tabular}

*correlation is significant at the 0.05 level (2-tailed)

** Correlation is significant at the 0.01 level (2-tailed). 


\subsection{Hypothesis Testing}

In order to analyse how a dependent variable is related to each of the independent variable, multiple regression model was used. When estimating the multiple regression equation, we expected the following relationship between the frequency of using investment evaluation techniques and sources of funds. We expected that sources of funds can influence how businesses evaluate investments. We expected that because of financial constraints, businesses will evaluate investments using the payback period and DCF method. The reason behind is that it will help the business to allocate investment funds over a multiyear horizon, and help identify the best projects.

\subsubsection{Results from the Regression Analysis}

In this study, sources of funds were: personal savings, family and friends, commercial banks, government assistance programmes, and other sources). Because the variables were categorical, then dummy variables were created. Thus for each category, one category was omitted because it is the reference. Thus the coefficients should be interpreted as the increase (a positive coefficient) or the decrease (a negative coefficient) in the B coefficients between the specified category and the reference category. In this regression analysis, the omitted category was personal savings. Three analyses were carried out in three equations each for the frequency of using payback period, ARR, and gut feel methods respectively, and the results are presented in tables.

The regression analysis on the sources of funds and the frequency of using payback period was performed. The prediction model was statistically significant, $\mathrm{F}(4,234)=3.61, \mathrm{p}<0.05$, and accounted for approximately $3.82 \%$ of the variance in the frequency of using payback period $\left(\mathrm{R}^{2}=0.0382\right)$. From Table 9, it is shown that in relation to personal savings, commercial banks are significant at $1 \%$, other sources at $5 \%$, and while family and friends and government assistance programmes are not at all significant. These results indicate that the use of payback period decreases as the business changes its source of funds from personal savings to commercial banks, and other sources while family and friends and government assistance programmes do not affect the use of payback period. Hence, the analysis shows that compared to personal savings, commercial banks and other sources, significantly affect the use of payback period, while, family and friends and government assistance programmes, do not significantly affect the use payback period.

Table 9. Estimation results for regression analysis on sources of funds and payback period

\begin{tabular}{lllll}
\hline Sources of funds & Coefficients & t-values & Sig.values & $\mathbf{R}^{\mathbf{2}}$ \\
\hline Family and friends & -.2339181 & -0.69 & 0.492 & \\
Commercial banks & -.7482038 & -2.69 & $\mathbf{0 . 0 0 8}$ & 0.0382 \\
Government assistance programmes & .7660819 & 1.49 & 0.137 & \\
Other & -2.233918 & -2.09 & $\mathbf{0 . 0 3 7}$ & \\
\hline
\end{tabular}

Source: Field data with own computations

The regression analysis on the sources of funds and the frequency of using ARR was performed. The prediction model was statistically significant, $\mathrm{F}(4,232)=9.54, \mathrm{p}<0.0005$, and accounted for approximately $3.82 \%$ of the variance in the frequency of using payback period $\left(\mathrm{R}^{2}=0.1412\right)$. From Table 10 , it is shown that in relation to personal savings, commercial bank is significant at $1 \%$, while family and friends, government assistance programmes, and other sources are not at all significant. These results indicate that the use of ARR decreases as the business changes its source of funds from personal savings to commercial banks, while family and friends and government assistance programmes, and other sources do not affect the use of ARR. Hence, the analysis shows that compared to personal savings, commercial banks, significantly affect the use of ARR, while, family \& friends and government assistance programmes, and other sources does not significantly affect the use payback period.

Table 10. Estimation results for regression analysis on the sources of funds and ARR

\begin{tabular}{lllll}
\hline Sources of funds & Coefficients & t-values & Sig.values & $\mathbf{R}^{\mathbf{2}}$ \\
\hline Family and friends & .172093 & 0.48 & 0.631 & \\
Commercial banks & -1.656478 & -5.89 & $\mathbf{0 . 0 0 0}$ & 0.1412 \\
Government assistance programmes & .497093 & 0.91 & 0.366 & \\
Other & -.127902 & -0.12 & 0.906 & \\
\hline
\end{tabular}

Source: Field data with own computation

On the other hand, Regression analysis on the sources of funds and the frequency of using gut feel was also carried out. The prediction model was statistically significant, $F(4,238)=2.10, \mathrm{p}<0.05$, and accounted for approximately $3.41 \%$ of 
the variance in the frequency of using payback period $\left(\mathrm{R}^{2}=0.0341\right)$. From Table 11, it is shown that in relation to personal savings, commercial bank is significant at $1 \%$, while family and friends, government assistance programmes, and other sources are not at all significant. These results indicate that the use of gut feel decreases as the business changes its source of funds from personal savings to commercial banks, while family \& friends and government assistance programmes, and other sources do not affect the use of gut feel. Hence, the analysis shows that compared to personal savings, commercial banks, significantly affect the use of gut feel, while, family and friends and government assistance programmes, and other sources do not significantly affect the use payback period.

Table 11. Estimation results for regression analysis on the sources of funds and gut feel

\begin{tabular}{lllll}
\hline Sources of funds & Coefficients & t-values & Sig.values & $\mathbf{R}^{\mathbf{2}}$ \\
\hline Family and friends & -.3913043 & -1.32 & 0.188 & \\
Commercial banks & -.6 & -2.42 & $\mathbf{0 . 0 1 6}$ & 0.0341 \\
Government assistance programmes & .3333333 & 0.73 & 0.466 & \\
Other & -.6666667 & -.86 & 0.392 & \\
\hline
\end{tabular}

Source: Field data with own computation

\section{Discussion}

The findings of this study shows that most SMEs finance their businesses from own savings, followed by commercial banks, family and friends, and other sources. When testing the simultaneous influence of sources of funds on the selection of investment evaluation techniques; own savings was found to have a positive influence on the use of payback period, ARR, and gut feel. The findings are consistent to the findings of the studies conducted by Danielson and Scott (2006) and Ahmed (2013) which observed a positive relationship between the availability of cash and technique used for investment decision.

These findings further show that businesses which source of funds is personal savings increase the use of payback period, while businesses whose source of funds is commercial banks and other sources decrease the use of payback period. We expected that sources of funds can influence how businesses evaluate investments. We expected that because of financial constraints, businesses will evaluate investments using the payback period and DCF method. The reason behind is that it will help the business to allocate investment funds over a multiyear horizon, and help identify the best projects. In this study, most SMEs their source of funds is personal savings (78.2\%). It was also found that, in relation to personal savings, commercial banks decrease the use of payback period, ARR, and gut feel.

Dependence of own savings in financing investments has an adverse effects in the investment decisions of SMEs, as it is obvious that these SMEs may not be in a position to make promising investments. Own source of funds may have limits. For SMEs which applied bank loans, they observed that the loans are costly in terms of service charges and interest. Moreover, often they were given less amount of money than what they applied. This will hinder SMEs to use recommended methods in evaluating investments due to lack of enough capital to finance investments. According to Ahmed (2013), the availability of cash is a good indicator of liquidity. So, businesses with large cash balances have opportunities to make new investments compared to the ones which do not have cash balances.

After testing the hypothesis for this study, it was found that sources of funds (own savings and commercial banks) influence the selection of investment evaluation techniques. Hence, the conclusion drawn from this study is that sources of funds are factors influencing the selection of investment evaluation techniques.

This study has theoretical and practical implications. Theoretically, the study contributed to the existing knowledge by identifying the sources of funds which significantly influenced the choice of investment evaluation techniques. The sources of funds are personal savings and commercial banks. Practically, SMEs should not depend only on own savings because this can constrain them to undertake profitable investments when SMEs do not have sufficient funds. Therefore, SMEs should make use of commercial banks which will force them to make proper investment decisions because they will have to convince the banks how they will have to pay back the loan. 


\section{References}

Abanis, T., Sunday, A., Birani, A., \& Eliabu, B. (2013). Financial Management practices in Small and Medium Enterprises in selected Districts in Western Uganda. Research Journal of Finance and Accounting, 4(2), 29-42.

Ahmed, I. (2013). Factors determining the selection of capital budgeting techniques, Journal of Finance and Investment Analysis, 2(2), 77-88.

Al-Kharus, A. (2003). Financing small business in Oman. PhD thesis of Loughborough University, UK.

Awomewe, A., \& Ogundele .O. (2008). The importance of the Payback method in Capital Budgeting Decision. MBA Thesis, Blekinge Institute of Technology.

Bates, J., \& Hally, D. (1982). The financing of small businesses $3^{\text {rd }}$ ed. London, Sweet and Maxwell.

Brijal, P., \& Quesada, L. (2009). The use of capital budgeting techniques in businesses; a perspective from the Western Cape, The journal of Applied Business Research, 25(4), 37-46.

Carrascal, C., \& Ferrando, A. (2008). The impact of Financial Position in the Euro Area: European Central Bank. Working Paper Series No. 943 September 2008.

Danielson, M., \& Scott, J. (2006). The capital budgeting decisions of small business. Journal of Applied Finance (Fall/Winter), 45-56.

Graham, J., \& Harvey ,C. (2001). The theory and practice of corporate finance: Evidence from the field. Journal of Financial Economics, 60(2-3), 187-243. https://doi.org/10.1016/S0304-405X(01)00044-7

Hartwig, F. \& Daunfeldt, S. (2012). What determines the use of capital budgeting methods? Evidence from Swedish listed companies. HUI working paper 57, Sweden, the Swedish Retail Institute (HUI).

He, W., \& Baker, K. (2007). Small business financing: Survey of evidence in West Texas The Journal of Entrepreneurial Finance and Business Ventures, 12(1), 29-54.

International Finance Corporation (2010). Scaling-up SME access to finance services in developing world. World Bank Group, Washington, DC.

John, M. S. (2007). Capital budgeting practices and performance of small firms in Tanzania. MBA Dissertation, University of Dar es Salaam. DOI 10.5195/emaj.2015.67

Karadag, H. (2015). Financial Management challenges in small and medium enterprises: a strategic management Approach. Emerging Markets Journal, 5(1). 25-40. https://doi.org/10.5195/EMAJ.2015.67

Keasey, K., \& Watson, R. (1993). Small firm management: Ownership, finance and performance. Great Britain: Blackwell Publishers.

Kipesha, E. (2009). Assessment of the investment analysis techniques used by SMEs and practices in Tanzania. The case of SMEs in Morogoro Municipality. MBA thesis, University of Dar es Salaam.

Levy, B. (1993). Obstacles to developing indigenous small and medium enterprises. An empirical assessmen. The World Bank Economic Review, 7(1), 65-83.

Liaw, T. (1999). The business of investing Banking. California: Wiley.

Makoni, P. L. (2014). Finance and firm characteristics in Tanzania. Banks and Bank Systems, 9(4), 92-98.

Mason, C., Harrison, J, \& Carter, R. (1998). Closing the equity gap? An assessment of the business expansion schema. London: Small Business Research Trust.

Mukherjee, T., \& Henderson, G. (1987). The capital budgeting process: Theory and practice. Interfaces, 17(2), 78-90. https://doi.org/10.1287/inte.17.2.78

Oakey, R. (1984). High technology small firms: Regional development in Britain and the USA. London: Frances Printer.

Olawale, F., Okubena, O. O., \& George, H. (2010). An investigation into the impact of investment appraisal techniques on the profitability of small manufacturing firms in the Nelson Mandela Bay Metropolitan Area, South Africa. African Journal of Business Management, 4(7), 1274-1280.

Omar, M. S. (2008). Financial constraints and structural characteristics of small and medium sized Enterprises (SMEs): The Case of Tanzania. Master Thesis, School of Economics and Management, Lund University.

Pandey, I. (1976). Essentials of financial management, 10thed. New-Delhi:Vikas Publishing House PVT.

Samuel, C. (1996). The Investment Decision: A re-examination of competing theories using panel data. The World Bank Policy Research Working Paper, 1656, Washington DC: World Bank. 
Srivastava, R., \&, Misra, A. (2008). Financial management, New Delhi: Oxford University Press.

Uddin, M., \& Chowdhury, R. (2009). Do We Need To Think More About Small Business Capital Budgeting? International Journal of Business Management, 4(1), 112-116. https://doi.org/10.5539/ijbm.v4n1p112

UNIDO (2013). Tanzania SME Development Policy 2003 “ten years after” URT (2003). Small and Medium Enterprises Development Policy.

URT (2013). 2012 Population and housing census. Population distribution by administrative areas. National Bureau of Statistics, Ministry of Finance, Tanzania.

Van, A. H., \& Carter, R. (1989). Acquisition of capitalization patterns. The Journal of Business Research, 5(2), 15-25.

Van, H., \& Wachowiz, J. (1995). Fundamentals of financial management. India: Prentice Hall.

Vos, A., \& Vos, E. (2000). Investment Decision Criteria In Small New Zealand. Businesses Small Enterprise Research, 8(1), 44-55. https://doi.org/10.5172/ser.8.1.44

Walliman, N. (2011). Research Methods: The Basics. London: Routledge

Weston, J. F., \& Brigham, E. F. (1981). Managerial Finance $7^{\text {th }}$ Ed. Hinsdale: The Dryden Press.

Yin, R. (2003). Case study research: designs and methods $3^{\text {rd }}$ ed. California: Sage Publications, Inc.

\section{Copyrights}

Copyright for this article is retained by the author(s), with first publication rights granted to the journal.

This is an open-access article distributed under the terms and conditions of the Creative Commons Attribution license which permits unrestricted use, distribution, and reproduction in any medium, provided the original work is properly cited. 